\title{
Oocyte-cumulus cell interactions regulate free intracellular zinc in mouse oocytes
}

\author{
R S Lisle, K Anthony, M A Randall and F J Diaz \\ Department of Animal Science, Center for Reproductive Biology and Health, The Pennsylvania State University, \\ 206 Henning Building, University Park, Pennsylvania 16802, USA \\ Correspondence should be addressed to F J Diaz; Email: fjd10@psu.edu
}

\begin{abstract}
Zinc increases in the oocyte during maturation and is required for progression and completion of meiosis. The objective of this study was to determine whether cumulus cells regulate the levels of free intracellular zinc in the oocyte during maturation. In the cumulus-oocyte complex (COC) the relative level of free intracellular zinc was almost fourfold higher in cumulus cells compared with the resident germinal vesicle-stage oocyte. Removal of cumulus cells caused a fourfold increase in intracellular zinc in the oocyte by $1 \mathrm{~h}$ after cumulus cell removal, but subsequent coculture of denuded oocytes with COC decreased free intracellular zinc in the oocyte by $65 \%$. Thus, cumulus cells suppress free intracellular zinc in the oocyte. The mRNA transcripts for the zinc transporter proteins Slc39a6, Slc39a8, Slc39a9, Slc39a10, Slc39a12, Slc30a2, Slc30a4, Slc30a5 and Slc30a8 mRNAs were higher in oocytes, while Slc39a1, SIc39a7, Slc39a13, Slc39a14, Slc30a6, Slc30a7 and Slc30a9 mRNAs were higher in cumulus cells. Thus a complex zinc transport network is present in the COC. Pretreatment with epidermal growth factor for $4 \mathrm{~h}$ abolished the ability of COCs to restrict free intracellular zinc in denuded oocytes. Coculture of denuded metaphase II oocytes with COC lowers free intracellular zinc in mature oocytes. Oocytes matured in vivo or oocytes from older mice had lower levels of free intracellular zinc than oocytes matured in vitro or from younger mice. Thus, a precise mechanism for regulating oocyte zinc homeostasis has been uncovered in the COC that is disrupted with increasing age or by removal of cumulus cells.

Reproduction (2013) 145 381-390
\end{abstract}

\section{Introduction}

Paracrine signaling in the cumulus-oocyte complex (COC) controls both oocyte and cumulus cell functions. Oocytes define the cumulus cell phenotype by promoting glycolysis (Sugiura et al. 2005), cholesterol synthesis (Su et al. 2008), proliferation (Vanderhyden et al. 1992, Gilchrist et al. 2006), survival (Hussein et al. 2005) and gene expression (Diaz et al. 2007), while suppressing luteinization (Pincus \& Enzmann 1935, Nekola \& Nalbandov 1971) and opposing FSH-stimulated gene expression (Diaz et al. 2007). The effects of oocytes on cumulus cells are mediated, in part, by factors such as GDF9 and BMP15, which activate the SMAD1/5/9 (Sugiura et al. 2007) and SMAD2/3 (Diaz et al. 2007) signaling pathways. Oocytes enable MAKP3/1 signaling in cumulus cells by promoting expression of the epidermal growth factor (EGF) receptor (Su et al. 2010). Cumulus cells, in turn, supply the oocyte with nutrients (Eppig et al. 2005, Sugiura et al. 2007, Su et al. 2008), induce transcriptional silencing (De La Fuente \& Eppig 2001) and prevent resumption of meiosis before ovulation (Pincus \& Enzmann 1935, Zhang et al. 2010).
Thus, the reciprocal and multilayered interactions between oocyte and cumulus cells are essential for oocyte development and fertility.

Recently, several reports have demonstrated unequivocally that elemental zinc is necessary for meiotic progression. Total zinc, including zinc bound to proteins, is very abundant in the oocyte before maturation (Kim et al. 2010) and is involved in preventing premature germinal vesicle $(\mathrm{GV})$ breakdown in GV-stage oocytes (Kong et al. 2012, Tian \& Diaz 2012). Total zinc increases during maturation and is required for the completion of the first meiotic division (Kim et al. 2010), although this is independent of the MOS-MAPK pathway (Bernhardt et al. 2011). Zinc is also required for establishment of metaphase II (MII) arrest through the regulation of the zinc-binding protein early meiosis inhibitor 2 (EMI2) (Suzuki et al. 2010b, Bernhardt et al. 2012). EMI2 inhibits the anaphasepromoting complex (APC) to block cyclin B1 ubiquitination and degradation during MII and is thus an essential component of the cytostatic factor activity in the mature oocyte (Masui \& Markert 1971, Shoji et al. 2006). EMI2 contains a zinc-binding region that is essential for 
blocking APC activity during MII arrest (Shoji et al. 2006, Suzuki et al. 2010a, 2010b). Exit from MII during oocyte activation requires a lowering of cellular zinc through the rapid export of zinc from the oocyte. These 'zinc sparks' are essential for oocyte activation and resumption of the cell cycle (Kim et al. 2011). These observations show that the precise regulation of intracellular zinc is essential for oocyte maturation and activation. However, the mechanisms regulating zinc homeostasis in the oocyte are unknown. In this study, we report that cumulus cells potently suppress free intracellular zinc in the oocyte through the production of a paracrine factor(s). Moreover, activation of EGF signaling abolishes the ability of cumulus cells to suppress free intracellular zinc, thereby allowing levels of free zinc to increase in the oocyte during maturation. Thus, zinc homeostasis is another process regulated in oocytes by the cumulus cells.

\section{Results}

\section{Relative levels of zinc in COC and denuded oocytes}

To begin examining the regulation of free intracellular zinc in the COC, we first determined the relative fluoZin3 signal intensity in freshly isolated COCs. There was a significantly higher level of free intracellular zinc in cumulus cells compared with the oocyte in intact COC (Fig. 1, $P<0.05$ ). To determine if the cumulus cells were blocking an increase in free zinc within the oocyte, cumulus cells were removed from freshly isolated COC which had been loaded with fluoZin-3. There was a twofold increase in free intracellular zinc within 15-30 min after cumulus cell removal and a fourfold increase after $1 \mathrm{~h}$ (Fig. 2). To test if coculture of denuded oocytes with COC could suppress levels of free intracellular zinc denuded oocytes were cultured alone or with COC for $15 \mathrm{~h}$. Oocytes cultured alone for 1 or $15 \mathrm{~h}$ had similar levels of free intracellular zinc (Fig. 3A, $B$ and D). However, when denuded oocytes cultured for $1 \mathrm{~h}$ alone were then cocultured with COC, there was a significant decrease in free intracellular zinc after $15 \mathrm{~h}$ (Fig. 3A and C, $P<0.05$ ).

\section{Expression of zinc transporters in cumulus cells and oocytes}

The relative mRNA concentrations of the zinc transporters were measured in denuded oocytes and cumulus cells. For the SLC39A zinc transporter family of proteins, Slc39a6, Slc39a8, Slc39a9, Slc39a10, Slc39a11 and Slc39a12 mRNAs were higher in oocytes compared with cumulus cells (Fig. 4A). In contrast, S/c39a1, Slc39a7 and Slc39a13 mRNAs were higher in cumulus cells (Fig. 4B). Slc39a14 mRNA was only detected in cumulus cells (data not shown). For the SLC30A family of zinc transporters, Slc30a2, Slc30a4, Slc30a5 and Slc30a8

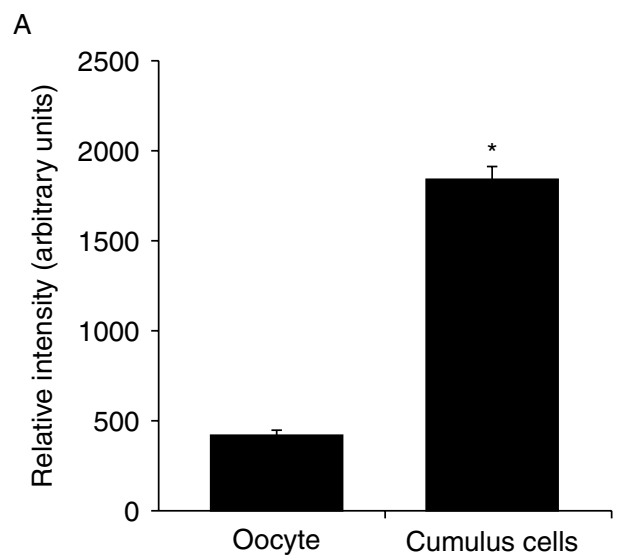

B

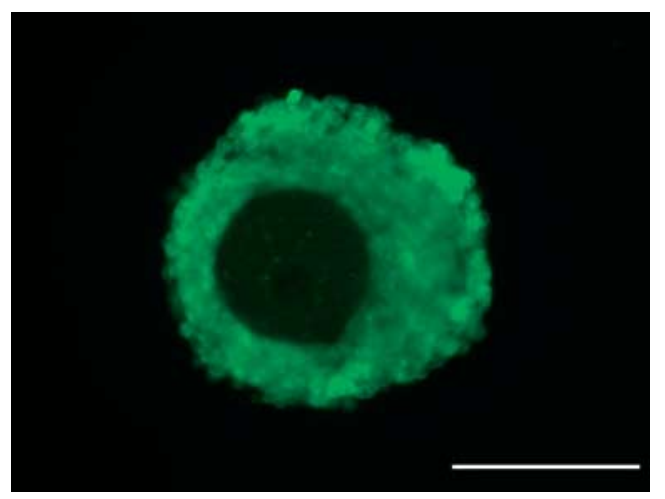

Figure 1 (A) FluoZin-3 fluorescence (arbitrary units) specifically in the oocyte and cumulus cell compartments and (B) representative fluorescent image of freshly isolated COCs loaded with fluoZin-3 $(2 \mu \mathrm{M})$ for $1 \mathrm{~h}$. ${ }^{*}$ Significant differences by Student's $t$-test, $P<0.05$, $n=4$. Scale $=100 \mu \mathrm{m}$.

mRNAs were higher in oocytes (Fig. 4A). Cumulus cells expressed higher Slc30a6, Slc30a7 and Slc30a9 mRNAs compared with oocytes (Fig. 4B). S/c39a3 and Slc30a1 mRNAs were equally expressed in both cell types (Fig. 4C). Slc39a4 and Slc39a5 mRNAs were not detected in either cumulus cells or oocytes (data not shown). SLC39A1 protein was localized in ovarian tissue sections using immunofluorescence staining. SLC39A1 protein was not detectable in primordial or early secondary follicles (Fig. 5A), but was robustly expressed in large secondary follicles (Fig. 5B) and in COC from antral follicles (Fig. 5C).

\section{Changes in suppressive properties of cumulus cells vs change in oocyte sensitivity during maturation}

The increase in oocyte zinc reported in the literature (Kim et al. 2010, 2011, Bernhardt et al. 2012) suggests that cumulus cells lose the ability to suppress free intracellular zinc in the oocyte or that maturing oocytes become insensitive to cumulus cells. To test these 


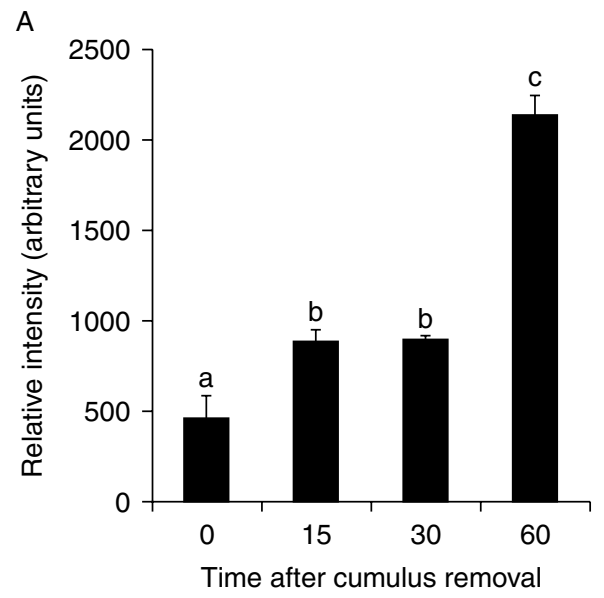

B
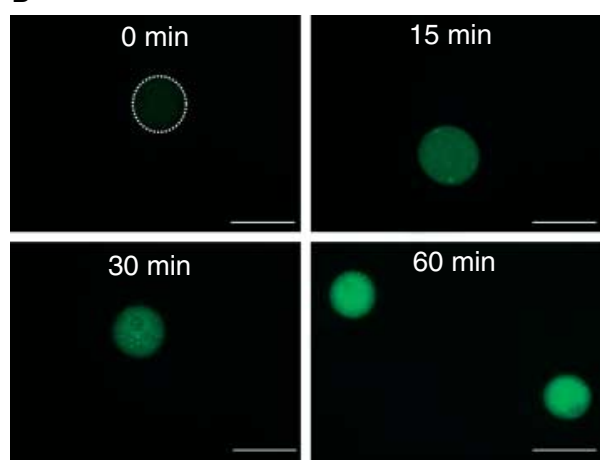

Figure 2 (A) FluoZin-3 fluorescence (arbitrary units) and (B) representative images of freshly denuded oocytes cultured for 0, 15, 30 and 60 min after loading with $2 \mu \mathrm{M}$ fluoZin-3 for $2 \mathrm{~h}$ while still in the COC. ${ }^{a, b, c}$ Significant difference, $P<0.05, n=3$. The white dotted circle indicates position of the oocyte at time $0 \mathrm{~h}$. Scale $=100 \mu \mathrm{m}$.

possibilities, denuded oocytes were cultured alone, with intact COC or with COC that had been pretreated with EGF $(10 \mathrm{ng} / \mathrm{ml})$ for $4 \mathrm{~h}$ to initiate COC maturation. As in previous experiments, culture of denuded oocytes alone led to a large increase in free intracellular zinc (Fig. 6A and $\mathrm{B}$ ). Coculture with intact $\mathrm{COC}$ prevented zinc from increasing (Fig. 6A and C). However, COC pretreated with EGF lost the ability to suppress a rise in free intracellular zinc in the oocyte (Fig. 6A and D). To test if mature MII oocytes lose the ability to respond to cumulus cells with a decrease in free intracellular zinc, mature MII oocytes were cultured alone or with intact COC for $15 \mathrm{~h}$. As expected, MII oocytes had a high level of free intracellular zinc but when MII oocytes were cocultured with COC zinc levels decreased by more than $50 \%$ (Fig. 7 ).

\section{Age and maturation conditions cause changes in oocyte free intracellular zinc}

The relative fluoZin-3 intensity was measured in oocytes matured in vitro with EGF $(10 \mathrm{ng} / \mathrm{ml})$ and in vivo after hormonal stimulation. In vitro maturation resulted in higher levels of free intracellular zinc in the oocyte compared with in vivo matured oocytes (Fig. 8). There also appeared to be overall higher intracellular zinc in cumulus cells matured in vitro compared with those collected in vivo. However, it was not possible to discriminate cell boundaries in individual cumulus cells to quantitatively measure changes in fluoZin-3 signal intensity in expanded complexes (Fig. 8B and C). We also determined if there are age-related effects on free intracellular zinc levels during maturation. There was no age effect in free intracellular zinc in GV oocytes from freshly isolated COC (Fig. 9A). However, in MII oocytes old mice (8-9 months) had modestly decreased levels of free intracellular zinc compared with young mice (3 weeks) (Fig. 9A, B and C). Additionally, intracellular zinc was uniformly distributed in MII oocytes from young mice (42/42 MII oocytes), but was restricted to part of the cytoplasm with an irregular distribution in all oocytes from old mice (29/29 MII oocyte) (Fig. 9C).

\section{Discussion}

The importance of oocyte-cumulus cell communication in the regulation of ovarian function was pioneered well over 75 years ago with the work by Pincus \& Enzmann (1935) who showed that oocytes secrete an antiluteinizing factor. Since then numerous studies have found that paracrine signals regulate many more important physiological processes in the follicle. Oocytes promote metabolic activity (Sugiura et al. 2005, Su et al. 2008), proliferation (Vanderhyden et al. 1992, Gilchrist et al. 2006) and differentiation (Diaz et al. 2007, Su et al. 2010) of cumulus cells. In this study, we present evidence that cumulus cells regulate zinc homeostasis in the oocyte. Cumulus cells regulate the timing of the increase in free intracellular zinc in the oocyte during maturation. This effect of cumulus cells is important because an increase in oocyte zinc is required for completion of meiosis (Kim et al. 2010, Bernhardt et al. 2011) and successful establishment of MII arrest (Suzuki et al. 2010 b, Kim et al. 2011). Thus, acute regulation of free intracellular zinc is a new process regulated by cumulus cell-oocyte interactions in the follicle.

A main finding of this study is that cumulus cells suppress the level of free intracellular zinc in oocytes before ovulation. It is important to stress that the zinc reporter (fluoZin-3) detects free or loosely bound intracellular zinc and not zinc tightly bound to proteins. The affinity of zinc for fluoZin-3 is $15 \mathrm{nM}$ (Gee et al. $2002 a, 2002 b)$. Zinc bound to cellular proteins with higher affinity would not be detected by this compound. Nevertheless, the results from the current study add more details regarding the regulation of zinc homeostasis in the COC during the periovulatory period. First, we present evidence that free intracellular zinc content is much lower in GV oocytes than in the surrounding 
A

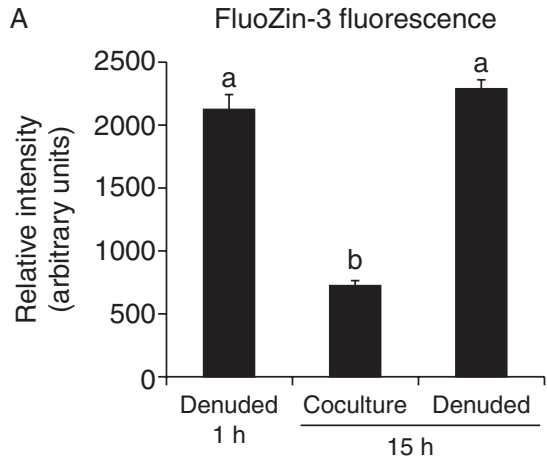

C

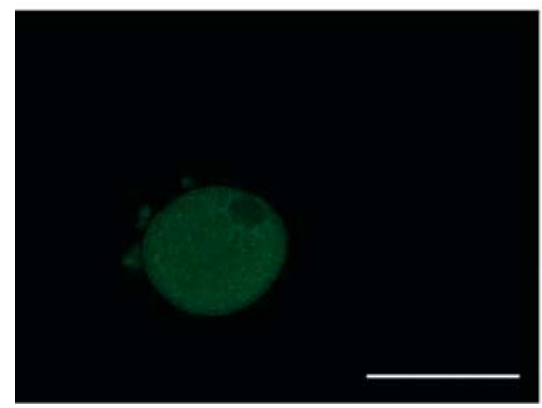

B

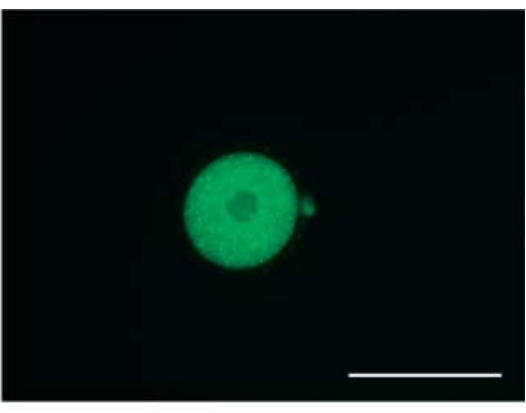

D

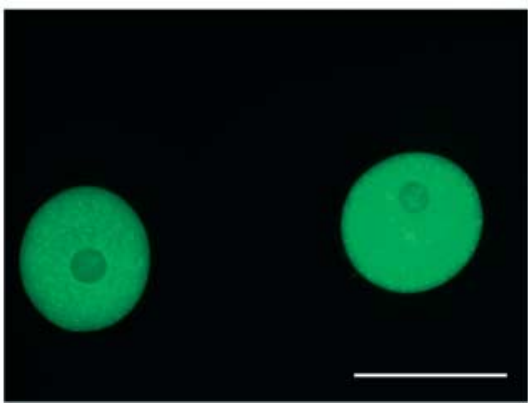

Figure 3 (A) FluoZin-3 fluorescence (arbitrary units) and representative images of (B) denuded oocytes cultured for $1 \mathrm{~h},(\mathrm{C})$ denuded oocytes cultured alone for $1 \mathrm{~h}$ and then with COC $(1 \mathrm{COC} / \mu \mathrm{l})$ for $15 \mathrm{~h}$ or $(\mathrm{D})$ denuded oocytes cultured alone for $15 \mathrm{~h}$. Oocytes were loaded with $2 \mu \mathrm{M}$ fluoZin-3 for $1 \mathrm{~h}$ prior to imaging. $a, b, c$ Significant differences by ANOVA and Tukey's post-hoc test, $P<0.05, n=3$. Scale $=100 \mu \mathrm{m}$. cumulus cells before maturation. The reason for lower free intracellular zinc in mouse oocytes is unclear but has been observed in other species including bovine and small chicken oocytes (data not shown). This suggests that an active mechanism maintains low free intracellular zinc in the oocytes of diverse species.

It is well accepted that the oocyte-cumulus cell regulatory loop is essential for producing high-quality oocytes (Matzuk et al. 2002). The oocyte produces many secreted factors that regulate cumulus cell function. Products such as GDF9, BMP15 and FGF8 regulate diverse functions in cumulus cells (Diaz et al. 2007, Sugiura et al. 2007). In contrast, we know much less about the cumulus cell factors that affect oocyte physiology. In this report, we show that cumulus cells potently suppress free intracellular zinc in oocytes. Moreover, coculture with COC causes a decrease in free intracellular zinc in both denuded GV and mature MII oocytes. How cumulus cells maintain low free intracellular zinc in the oocyte is not known. Cumulus cells could stimulate zinc export, inhibit zinc import or promote the sequestration of free intracellular zinc within specific cellular compartments. It is intriguing to speculate that cumulus cells could alter the distribution of zinc from different intracellular compartments or organelles, but this remains to be tested. At least some of the increase in oocyte zinc during maturation is due to influx from extracellular sources because the total number of zinc ions increases during maturation (Kim et al. 2010). Whether extracellular zinc also enters the
GV-stage oocyte after cumulus cell removal remains to be determined.

The specific transporter(s) that regulate zinc transport within the oocyte or from the extracellular environment are unknown. There are 14 known zinc importers of the SLC39A family and nine intracellular zinc transporters of the SLC30A family in mice and humans (Kambe et al. 2004, Lichten \& Cousins 2009). The expression of many of these transporters was found in mouse oocytes and cumulus cells. Slc39a6, Slc39a8, Slc39a9, Slc39a10, Slc39a12, Slc30a2, Slc30a4, Slc30a5 and Slc30a8 mRNAs were higher in oocytes, while Slc39a1, Slc39a7, Slc39a13, Slc39a14, Slc30a6, Slc30a7 and Slc30a9 mRNAs were higher in cumulus cells. Our results confirm previous findings. For example, SLC39A10 protein was previously localized to oocytes and not somatic follicular cells (Malcuit et al. 2009). Given the vital importance of zinc for many cellular processes it is not surprising that multiple transporters are present in the oocyte. Exactly where these are localized and how each transporter is involved in modulating zinc flux into and out of the oocyte as well as between different intracellular compartments are important questions that remain to be answered. The localization of SLC39A1 in oocytes from secondary and larger follicles, but not primordial or primary follicles, suggests that the expression of zinc transport proteins may be developmentally regulated. Thus, it will be important to determine changes in other transporter proteins over the course of folliculogenesis. It will also be important to 

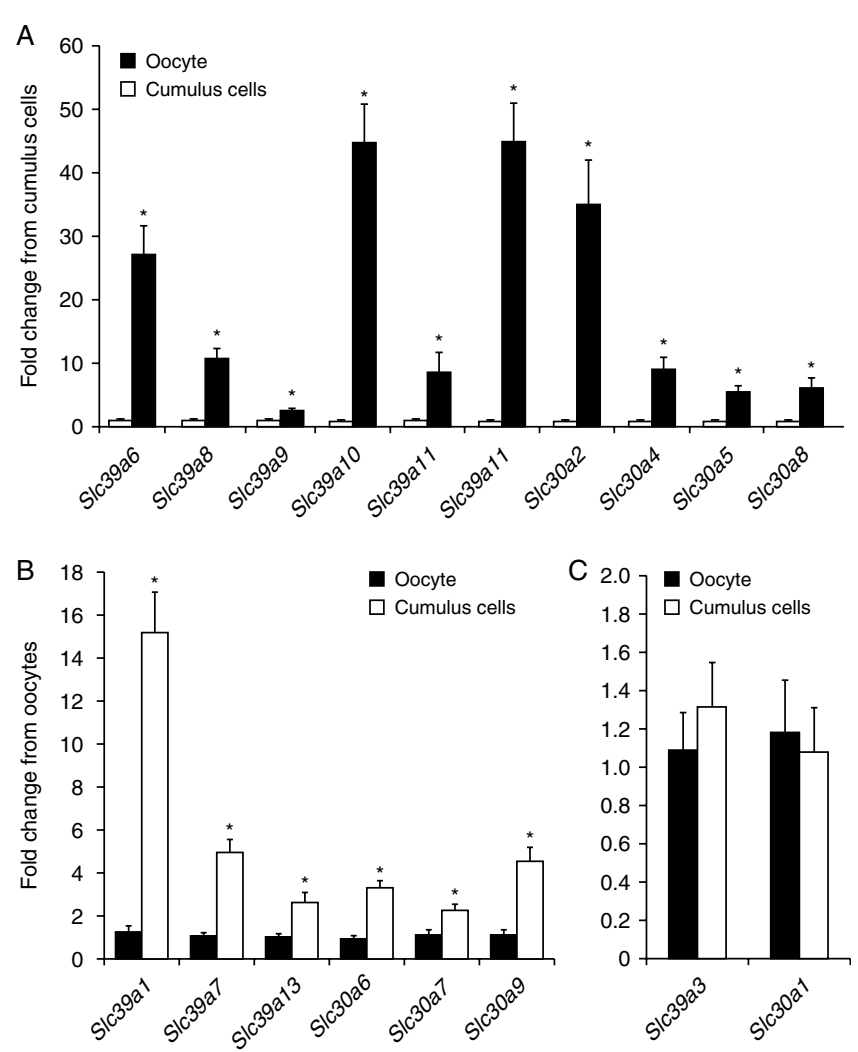

Figure 4 Relative expression (fold change) of S/c39a and S/C30a zinc transporters analyzed by qPCR which are (A) higher in oocytes, (B) higher in cumulus cells or (C) not changed. *Significant differences by Student's $t$-test, $P<0.05, n=4$.

determine which transport proteins are important in cumulus cells as a potential source of zinc for the oocyte and for cumulus cell functions such as pSMAD activation and cumulus expansion (Tian \& Diaz 2012).

The increase in oocyte zinc during in vitro maturation (Kim et al. 2010) suggests that either cumulus cells lose the ability to suppress zinc in the oocyte or the maturing oocyte loses the ability to respond to cumulus cells. To distinguish between these possibilities, we examined the ability of a maturation signal (EGF) to block the ability of cumulus cells to suppress levels of free intracellular zinc in the oocyte. Pretreatment of COC with EGF for just $4 \mathrm{~h}$ was sufficient to prevent the COC-induced decrease in free intracellular zinc in denuded oocytes. However, the mature MII oocyte remains sensitive to cumulus cells because coculture of mature MII oocytes with untreated COC causes a decrease in intracellular zinc. Thus, we conclude that cumulus cells lose the ability to suppress free intracellular zinc and that this change is essential to allow the normal increase in oocyte zinc content during maturation. Interestingly, we found that free intracellular zinc is higher in oocytes matured in vitro than in vivo. Perhaps cumulus cells become less effective at suppressing oocyte zinc concentrations in vitro, which would cause greater increase in oocyte zinc. It was also apparent that zinc content was greater in cumulus cells matured in vitro compared with in vivo. The significance of this is unclear, but we have recently shown that zinc is required to maintain activation of TGF- $\beta$ signaling pathways, in particular pSMAD2, in cumulus cells (Tian \& Diaz 2012). Normally pSMAD2 signaling is abolished during maturation (Diaz et al. 2007, Tian et al. 2010). Higher zinc levels in cumulus cells matured in vitro may maintain higher pSMAD2 signaling in cumulus cells. Oocytes matured in vitro are less fertile than those matured in vivo, at least for women with polycystic ovarian syndrome (Child et al. 2002, Gremeau et al. 2012). It could be that altered zinc homeostasis in oocytes or cumulus cells in vitro disrupts oocyte maturation and/or cumulus cell function.

Aging also has a potentially significant effect on oocyte zinc homeostasis. In in vitro-ovulated oocytes from old mice (8-9 months) have lower zinc content compared
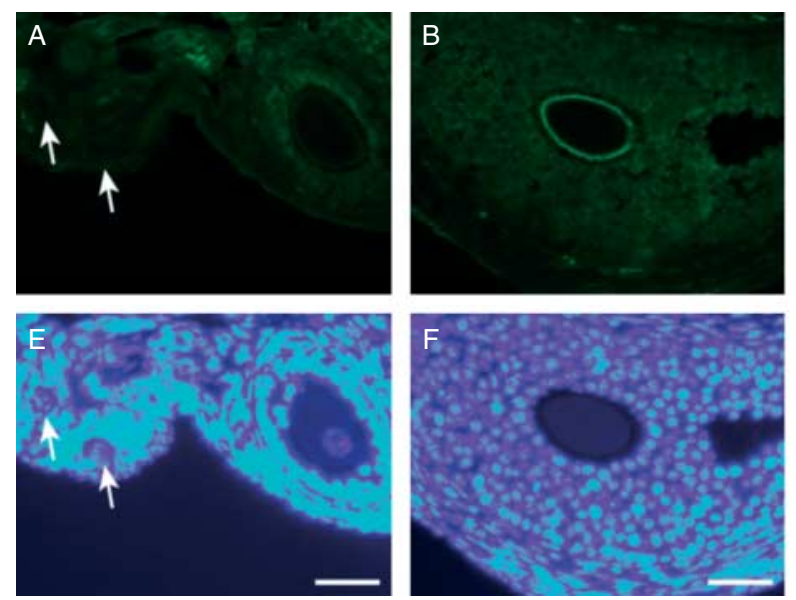
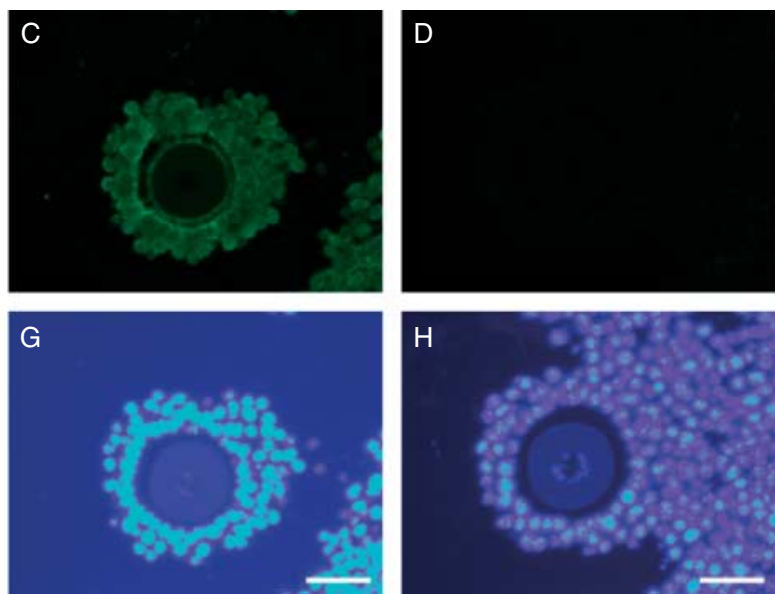

Figure 5 Immunolocalization of SLC39A1 protein in (A) primordial (white arrows) and primary follicles, (B) large secondary follicle and (C) COC from antral follicle in ovarian sections of normal mice. (D) Negative control incubated without primary antibody. (E, F, G and H) Corresponding DAPI images of panels (A, B, C and D) respectively. Scale $=50 \mu \mathrm{m}$. 
A

FluoZin-3 fluorescence

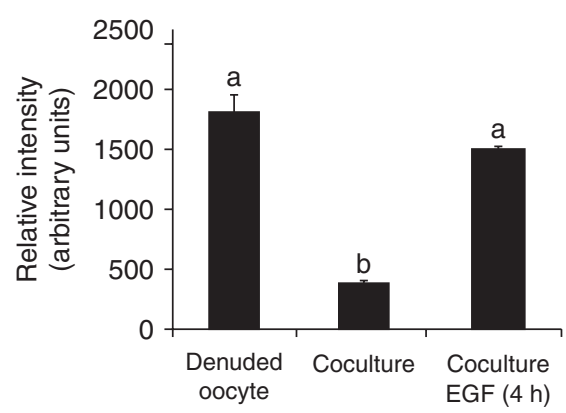

C

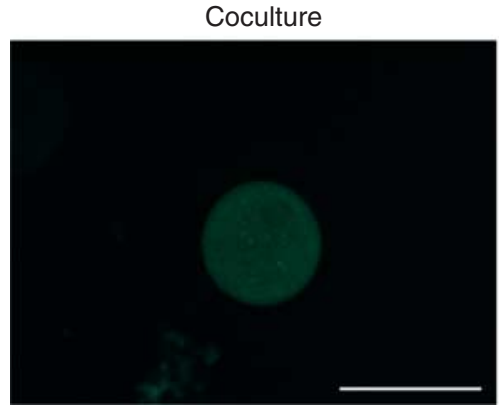

B

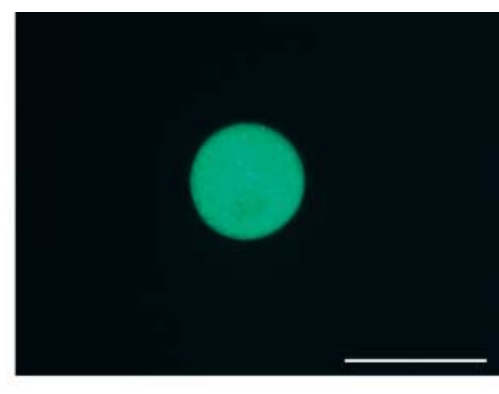

D

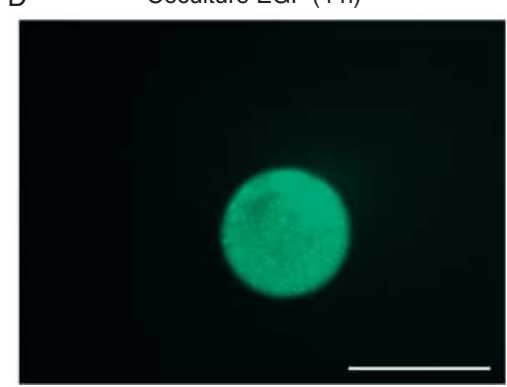

Figure 6 (A) FluoZin-3 fluorescence (arbitrary units) and representative images of (B) denuded oocytes cultured for $15 \mathrm{~h},(\mathrm{C})$ denuded oocytes cocultured with COC $(1 \mathrm{COC} / \mu \mathrm{l})$ for $15 \mathrm{~h}$ or (D) denuded oocytes cultured for $15 \mathrm{~h}$ with COC which were pretreated with EGF for $4 \mathrm{~h}$. Oocytes were loaded with $2 \mu \mathrm{M}$ fluoZin-3 for $1 \mathrm{~h}$ prior to imaging.

a,b,c Significant differences by ANOVA and Tukey's post-hoc test, $P<0.05, n=3$. Scale $=100 \mu \mathrm{m}$. with those from young mice ( 3 weeks). Moreover, the distribution of free intracellular zinc was not uniform in the cytoplasm of oocytes from old mice compared with those from young mice. This suggests that the intracellular zinc transport network may be disrupted in oocytes of older individuals. Lower amount of free intracellular zinc in MII oocytes from older mice could explain why these oocytes are more prone to aneuploidy (Merriman et al. 2012). Zinc increases in the oocyte during maturation and is required for completion of meiosis I (Kim et al. 2010). If zinc does not increase sufficiently in older oocytes, there could be problems with subsequent completion of the first meiotic division and chromosome segregation. These effects would be similar to meiotic defects observed after zinc depletion in vitro (Kim et al. 2010) and in vivo (Tian \& Diaz 2012). Another possibility is that oocytes from older mice undergo premature activation due to insufficient zinc levels to maintain MII arrest. Previous research shows that zinc is essential to maintain MII arrest (Masui \& Markert 1971, Shoji et al. 2006). However, at fertilization zinc oscillations are required for oocyte activation (Kim et al. 2011). Thus, increasing free intracellular zinc in aged oocytes could potentially improve fertility by regulating zinc-mediated meiotic and oocyte activation pathways.

Assisted reproduction therapies target the periovulatory period through extensive hormonal stimulation and in vitro manipulations to produce sufficient numbers of embryos for transfer to the uterus. Problems during maturation can disrupt programming of the maternal and/or embryonic genome resulting in epigenetic defects that affect development and even postnatal health (Doherty et al. 2000, Mann et al. 2004, Rivera et al. 2008). Dramatic effects of zinc deficiency have been uncovered in oocytes (Kim et al. 2010, Suzuki et al. 2010b) and cumulus cells (Tian \& Diaz 2012) during the periovulatory transition. Currently, the success of human IVM is highly variable (4-35\% clinical pregnancy/ transfer) (Cha et al. 1991, Trounson et al. 1994, Child et al. 2001, Gremeau et al. 2012, Guzman et al. 2012). The ability to reliably mature oocytes in vitro would reduce reliance on human chorionic gonadotropin (hCG) injections which are associated with ovarian hyperstimulation syndrome (Aboulghar \& Mansour 2003). The
A

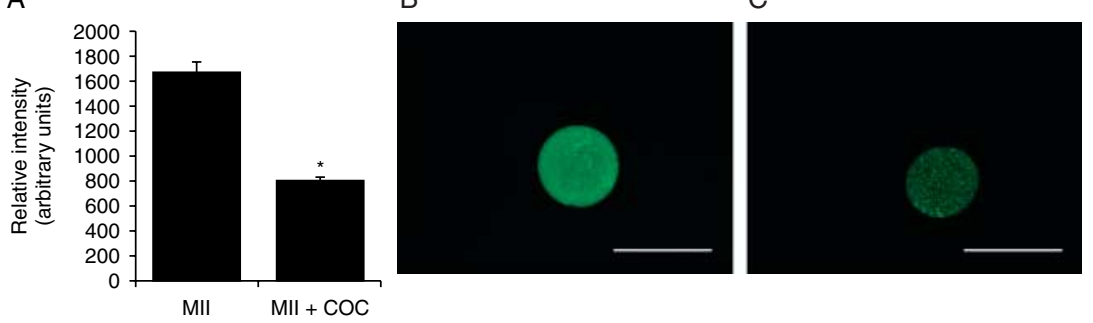

Figure 7 (A) FluoZin-3 fluorescence (arbitrary units) and representative images of (B) ovulated MII oocytes collected after eCG (48 h) and hCG (13 h) hormonal stimulation and cultured for $15 \mathrm{~h}$ alone or (C) ovulated MII oocytes cultured with COC $(1 \mathrm{COC} / \mu \mathrm{l})$ for $15 \mathrm{~h}$. Oocytes were loaded with $2 \mu \mathrm{M}$ fluoZin-3 for $1 \mathrm{~h}$ prior to imaging. *Significant differences by Student's $t$-test, $P<0.05, n=4$. Scale $=100 \mu \mathrm{m}$. 
A

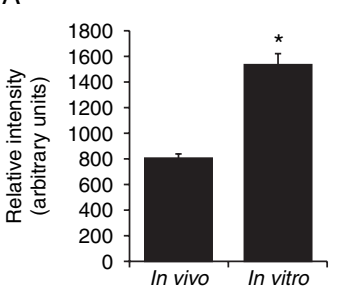

B

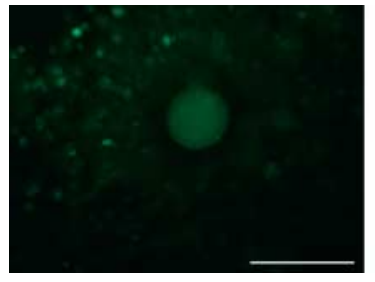

Figure 8 (A) FluoZin-3 fluorescence (arbitrary units) in the oocyte and representative images of COC matured (B) in vivo with eCG/hCG or (C) in vitro with $10 \mathrm{ng} / \mathrm{ml}$ EGF. Oocytes were loaded with $2 \mu \mathrm{M}$ fluoZin-3 for $1 \mathrm{~h}$ prior to imaging. *Significant differences by Student's t-test, $P<0.05, n=6$. Scale $=100 \mu \mathrm{m}$. precise regulation of zinc homeostasis (Kim et al. 2011, this study) in the oocyte is emerging as an important parameter of oocyte quality. This knowledge could lead to improved in vitro maturation procedures in humans by modulating oocyte zinc levels to improve completion of meiosis or oocyte activation.

\section{Materials and Methods}

\section{Animals}

Female CD1 mice (Mus musculus) were produced and raised in the research colony of the investigators. Ovaries were collected from 20-day-old (young) or 8-9-month old (old) mice primed with $5 \mathrm{IU}$ equine chorionic gonadotropin (eCG) (National Hormone and Peptide Program (NIDDK)) for 44-48 h. Ovulation was induced in some animals with hCG (5 IU) $48 \mathrm{~h}$ after eCG treatment. Animals were maintained according to the Guide for the Care and Use of Laboratory Animals (Institute for Learning and Animal Research). All animal use was reviewed and approved by the IACUC committee at The Pennsylvania State University.

\section{Isolation of COC and oocytes}

Ovaries were collected aseptically and placed in a 35-mm culture dish containing medium (bicarbonate-buffered MEM- $\alpha$ (Life Technologies, Inc.) with Earle's salts, 75 mg penicillin G/l, $50 \mathrm{mg}$ streptomycin sulfate/l, $0.23 \mathrm{mM}$ pyruvate and $3 \mathrm{mg}$ $\mathrm{BSA} / \mathrm{ml}$ (Cohn Analog purified; Sigma). COCs were released from the antral follicles by gentle puncture with a syringe and needle and manually washed though three dishes of media with a mouth-operated glass pipette. In some experiments oocytes were denuded by passing through a small-bore glass pipette. Ovulated COCs were collected from the oviduct of eCG/hCG-treated animals.

\section{Zinc measurements using fluoZin-3 AM indicator dye}

COCs or denuded oocytes were loaded in $20 \mu \mathrm{l}$ medium containing the amyl ester of the fluorophore, fluoZin-3 AM ( $2 \mu \mathrm{M}$; Invitrogen, excitation $494 \mathrm{~nm} /$ emission $516 \mathrm{~nm}$ ), for 1 or $2 \mathrm{~h}$ at $37^{\circ} \mathrm{C}$ followed by washing briefly in fresh medium and mounting on glass slides with etched rings to prevent rupture of the oocytes and covered with a coverslip. Immediate imaging provided the most repeatable results, although the signal was very stable for up to $30 \mathrm{~min}$ under the microscope with little bleaching. The pixel intensity per unit area after background subtraction was determined in GV oocytes, MII oocytes and cumulus cells (Fig. 1) with an AxioScope 2 Plus fluorescence microscope (Leica, Bannockburn, IL, USA) with attached AxioCam camera (Zeiss, Thornwood, NY, USA) and Axiovision Software (Zeiss, Thornwood, NY, USA). FluoZin-3 has been extensively characterized for measurements of free intracellular zinc in live cells using microscopy and has an affinity constant $\left(K_{\mathrm{d}}\right)$ for zinc of $15 \mathrm{nM}$ (Gee et al. 2002a, 2002b).

\section{Culture of COCs and oocytes}

COCs and fully grown oocytes were cultured in bicarbonatebuffered MEM- $\alpha$ (Life Technologies, Inc.) with Earle's salts, supplemented with $75 \mathrm{mg}$ penicillin G/l, $50 \mathrm{mg}$ streptomycin sulfate/l, $0.23 \mathrm{mM}$ pyruvate and $3 \mathrm{mg} \mathrm{BSA} / \mathrm{ml}$ in a Galaxy $14 \mathrm{~S}$ incubator under an atmosphere of $5 \% \mathrm{O}_{2}, 5 \% \mathrm{CO}_{2}$ and $90 \%$ nitrogen for all experiments. For measurements of free intracellular zinc in GV oocytes milrinone $(10 \mu \mathrm{M})$ was included in the medium to maintain the GV intact. For coculture experiments GV or MII oocytes (10 oocytes/20 $\mu \mathrm{l})$ were cultured in bicarbonate-buffered MEM- $\alpha$ under oil. In some experiments intact COCs were added (1 COC/ $\mu \mathrm{l})$ to the culture drops for up to $15 \mathrm{~h}$. For in vitro maturation COCs were collected from eCG-primed mice $(48 \mathrm{~h})$ in bicarbonate-buffered MEM- $\alpha$ and matured in medium
A

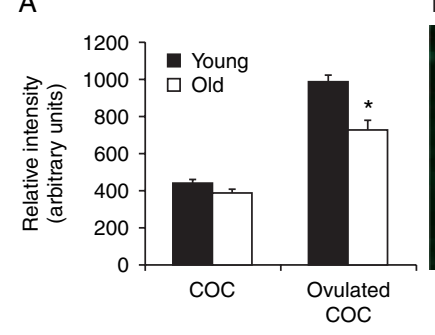

B

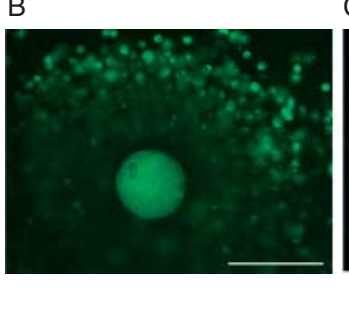

C

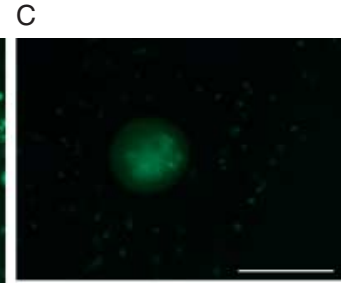

Figure 9 (A) FluoZin-3 fluorescence (arbitrary units) in the GV and MII oocytes from young (3 weeks) and old (8-9 months) mice primed with eCG $(n=4)$ and young and old mice superovulated with eCG/hCG $(n=4$, young; $n=6$, old). Representative images of MII oocytes from ovulated complexes from (B) young and (C) old female mice. Oocytes were loaded with $2 \mu \mathrm{M}$ fluoZin-3 for $1 \mathrm{~h}$ prior to imaging. *Significant differences by Student's $t$-test, $P<0.05$. Scale $=100 \mu \mathrm{m}$. 
containing EGF $(10 \mathrm{ng} / \mathrm{ml})$ for $16 \mathrm{~h}$ as described previously (Diaz et al. 2007).

\section{Free intracellular zinc in freshly isolated COC}

To determine the relative levels of free intracellular zinc in cumulus cells and oocytes freshly isolated COCs were collected $48 \mathrm{~h}$ after eCG and loaded with fluoZin-3 for $1 \mathrm{~h}$. Signal intensity was measured in the oocyte and an equal area of surrounding cumulus cells. A total of 15 COCs from four female mice were used for these measurements.

\section{Free intracellular zinc in denuded oocytes}

To measure the effect of cumulus cell removal on oocyte free intracellular zinc COCs were collected $48 \mathrm{~h}$ after eCG priming and were loaded with fluoZin-3 AM $(2 \mu \mathrm{M})$ for $2 \mathrm{~h}$. Cumulus cells were removed from the GV oocytes by passing the COC gently through a small-bore glass pipette several times. Denuded oocytes were then imaged at 0, 15, 30 and 60 min after cumulus removal by fluorescence microscopy. At each time point 21-35 oocytes were measured. The experiment was repeated three times.

\section{Coculture of denuded oocytes with COC}

For the coculture experiments denuded GV-stage oocytes were cultured for $1 \mathrm{~h}$ to allow an increase in free intracellular zinc. Oocytes were then cultured alone or with freshly isolated COC (collected $48 \mathrm{~h}$ after eCG) for $15 \mathrm{~h}$ in medium containing milrinone to prevent maturation of oocytes within the COC. Preliminary experiments indicated that maximum inhibition of oocyte zinc occurred by $15 \mathrm{~h}$. One hour before the end of culture $2 \mu \mathrm{l}$ of a 100- $\mu \mathrm{M}$ stock solution of fluoZin-3 were added to the culture drops and incubated for $1 \mathrm{~h}$ to load the cells with the zinc indicator dye and the denuded oocytes were imaged as described above. For each group, 20-30 oocytes were used and the experiment was repeated three times.

\section{Coculture of denuded oocytes with COC pretreated with EGF}

To measure the effect of pretreatment with EGF on free intracellular zinc in the oocyte, freshly denuded oocytes were transferred to medium supplemented with milrinone $(10 \mu \mathrm{M})$ and cultured alone, with untreated COC previously cultured for $4 \mathrm{~h}(1 \mathrm{COC} / \mu \mathrm{l})$ or with COC previously treated with EGF $(10 \mathrm{ng} / \mathrm{ml})$ for $4 \mathrm{~h}$. After $14 \mathrm{~h}$ oocytes were loaded with fluoZin-3 for $1 \mathrm{~h}$ and imaged as described previously. For each group 20-30 oocytes were used and the experiment was repeated three times.

\section{Coculture of mature MII oocytes with COC}

To test if matured MII oocytes respond to COC coculture with a decrease in free intracellular zinc, mature MII oocytes were collected from the oviduct of superovulated (eCG/hCG) mice. Cumulus cells were removed with hyaluronidase $(2 \mathrm{mg} / \mathrm{ml})$ and gentle pipetting. MII oocytes were cultured for $15 \mathrm{~h}$ in media containing $10 \mu \mathrm{M}$ milrinone, either alone or with freshly isolated COC. One hour before the end of culture fluoZin-3 $(2 \mu \mathrm{M})$ and Hoechst $(5 \mu \mathrm{g} / \mathrm{ml})$ were added to the culture drops and incubated for $1 \mathrm{~h}$ and oocytes were imaged as described above to measure fluoZin-3. For each group, 28-29 MII oocytes were imaged and the experiment was repeated four times.

Table 1 Primer sequences used for qPCR.

\begin{tabular}{|c|c|c|c|c|}
\hline & Forward & Reverse & Accession no. & Amplicon (bp) \\
\hline Slc39a1 & GGTCTCTCTGCCAGTTTTCG & CAGCATTAAGGAGGCAGAGG & NM_013901 & 161 \\
\hline Slc39a2 & ССTGСTTGСTСTTCTGGTTC & ССТССАGAGСTTCAGCAGTC & NM_001039676 & 179 \\
\hline Slc39a3 & CCATGGTTCACACACAGAGG & AGGGTCCСTGAGGTCACTTT & NM_134135 & 236 \\
\hline Slc39a4 & СTTGGCTCTAGGCAAACCTG & AGTGTGGCCAGGTAATCGTC & NM_028064 & 177 \\
\hline Slc39a5 & GCCAGAGGGAGAACAGACAG & GTGGCAGAAGACTGCTAGGG & NM_001136237 & 206 \\
\hline Slc39a6 & TTCСTGTCTСTGСTGGGAGT & TGTGCTGATGACTTGCATGA & NM_139143 & 154 \\
\hline Slc39a7 & AGGAGTGTCAGCСTTGGAGA & ATTAGGGACCATCGGGTAGG & NM_001077709 & 189 \\
\hline Slc39a8 & AGCCTAACGGACACATCCAC & AGTACAAGATGCCCCAATCG & NM_001135150 & 191 \\
\hline Slc39a9 & GCATTAGAGGCAGCAGGAAC & GCATTAAGGCATCCACACCT & NM_026244 & 166 \\
\hline Slc39a10 & TACCCACCAGCATTTTCACA & TCACTGTGAGCAACGGAGTC & NM_172653 & 237 \\
\hline Slc39a11 & СТTСTTCACСТGGGCAATGT & GGAGGTCAGCCAGGTAGACA & NM_027216 & 248 \\
\hline Slc39a12 & GACTGCAAGCTGTGTTTGGA & CTAAGGCCGAGTAGGCTGTG & NM_001012305 & 203 \\
\hline Slc39a13 & GCCTGTCGCCTGGATAATAA & ССАССТАAGGCAAAGСТGAG & NM_026721 & 215 \\
\hline Slc39a14 & TCAGCCGTGTGCTCACTTAC & GGTGCTCGTTTTTCTGCTTC & NM_001135152 & 204 \\
\hline Slc30a1 & GСTCTCGAGTTGGTCСTGTC & GCСTCATGGTGAGGTAGGAA & NM_009579 & 159 \\
\hline Slc30a2 & TTCTGGAAGTCACССТGACC & CTAATGAGCATGCTGGCAAA & NM_001039677 & 177 \\
\hline Slc30a3 & CСАTCAGCАССТTССТСТTC & ATGGAGATCATGGGTTGCTC & NM_011773 & 167 \\
\hline Slc30a4 & TGCCGTCСTCTACTTGСTTT & TAGGCGATGAAATCCAAAGG & NM_011774 & 187 \\
\hline Slc30a5 & TTGGTTTTCATACGGCTTCC & TTTGGACACGTCCATTTTGA & NM_022885 & 248 \\
\hline Slc30a6 & GTCCACGCTGACTGTTCAGA & CGTTTTTCCCAGGCGTATTA & NM_001252478 & 215 \\
\hline Slc30a7 & GCCACCATACCGAGTCACTT & CCACAAAAGCGAAAGAGAGG & NM_001191715 & 214 \\
\hline Slc30a8 & ACTGATGCGGCTCATCTCTT & GATGCAAAGGACAGACAGCA & NM_172816 & 150 \\
\hline Slc30a9 & GTCACCCACGGTCTCTCATT & АСТGССТGTTCСАAАACСAC & NM_178651 & 186 \\
\hline Slc30a10 & TGTGCATGCTAAGGAACTGC & CACGGTCCAAGAATGGACTT & NM_001033286 & 248 \\
\hline Rp/19 & TTCAAAAACAAGCGCATCСТ & СTTTCGTGCTTCCTTGGTCT & NM_009078 & 120 \\
\hline
\end{tabular}




\section{Free intracellular zinc in oocytes matured in vivo and in vitro}

To stimulate cumulus expansion and maturation in vitro freshly isolated COCs were cultured with EGF $(10 \mathrm{ng} / \mathrm{ml})$ for $16 \mathrm{~h}$ as described previously (Diaz et al. 2007). In vivo matured complexes were collected from the oviduct of female mice stimulated with eCG $(48 \mathrm{~h})$ and hCG $(13 \mathrm{~h})$. In vivo- and in vitro-matured complexes were loaded with flouzin-3 for $1 \mathrm{~h}$ and imaged as described above. For each group, 8-10 MII oocytes were imaged and the experiment was repeated a total of six times.

\section{Free intracellular zinc in $G V$ and $M I I$ oocytes from young and old mice}

To collect GV complexes young (20-days-old) and old (8-9months-old) mice, animals were primed with eCG. Intact COCs were loaded with fluoZin-3 and the signal intensity in the oocyte was determined. For each group, 21-28 oocytes were measured and the experiment was repeated a total of four times. To measure zinc content in MII oocytes, young and old mice were superovulated (eCG/hCG) and the expanded complexes were collected from the oviduct and loaded with fluoZin-3 for $1 \mathrm{~h}$ and imaged as described above. For each group, 5-8 MII oocytes were measured and the experiment was repeated four to six times for a total of 42 oocytes from young mice and 29 oocytes from old mice.

\section{Isolation of $m R N A$ and $q P C R$}

Total RNA was isolated from 20 GV oocytes and cumulus cells from 20 complexes using the RNAeasy micro kit (Qiagen, Valencia, CA, USA). Total RNA was reverse transcribed into cDNA as described previously (Diaz et al. 2006) using the Quantitect cDNA synthesis kit (Qiagen, Valencia, CA, USA). Quantification of zinc transporter mRNAs was analyzed by the $2^{-\Delta \Delta C t}$ method using gene-specific primers (Table 1) and Rp/19 mRNA as the normalizer as described previously (Livak \& Schmittgen 2001, Diaz et al. 2006). Cumulus cells and oocytes were used as calibrator samples in Fig. 4A and B respectively. Zinc transporter primer sequences were validated previously (Kelleher et al. 2012). The experiment was repeated four times with separate groups of oocytes and cumulus cells. Values shown are the mean \pm S.E.M.

\section{Immunofluorescence}

Sections from eCG-primed ovaries were fixed in $4 \%$ paraformaldehyde for $4-6 \mathrm{~h}$ and embedded in paraffin. Sections $(5 \mu \mathrm{m})$ were placed on slides, dewaxed and blocked for $1 \mathrm{~h}$, followed by incubation with anti-SLC39A1 primary antibody (1:400) (Jou et al. 2009) for $2 \mathrm{~h}$ at room temperature. Slides were washed and incubated with secondary antibody (goat anti-chicken IgG labeled with Alexa Fluor-488; Invitrogen, excitation $495 \mathrm{~nm}$ /emission $519 \mathrm{~nm}$ ) for 30 min followed by washing three times with PBST and mounting with anti-fade gold with 4',6-diamidino-2-phenylindole (DAPI) (Invitrogen, Carlsbad, CA, USA) and imaged on an AxioScope 2 Plus epifluorescence microscope (Leica, Bannockburn, IL, USA) and DP20 Olympus digital color camera and DP Software (Olympus, Center Valley, PA).

\section{Statistical analysis}

Flouzin-3 signal intensity and qPCR results were analyzed by either Student's t-test or one-way ANOVA and Tukey's post-hoc test as appropriate. A $P$ value of $<0.05$ was considered significant. Data were confirmed to be from a normal distribution with equal variance using the goodness-of-fit test and F-statistic in the JMP Analysis Software (SAS, Cary, NC).

\section{Declaration of interest}

The authors declare that there is no conflict of interest that could be perceived as prejudicing the impartiality of the research reported.

\section{Funding}

This work was supported by the College of Agricultural Sciences (COAS) start-up funds, and a research grant (grant number HD057283) from the National Institutes of Health to F J Diaz.

\section{References}

Aboulghar MA \& Mansour RT 2003 Ovarian hyperstimulation syndrome: classifications and critical analysis of preventive measures. Human Reproduction Update 9 275-289. (doi:10.1093/humupd/dmg018)

Bernhardt ML, Kim AM, O'Halloran TV \& Woodruff TK 2011 Zinc requirement during meiosis I-meiosis II transition in mouse oocytes is independent of the MOS-MAPK pathway. Biology of Reproduction $\mathbf{8 4}$ 526-536. (doi:10.1095/biolreprod.110.086488)

Bernhardt ML, Kong BY, Kim AM, O'Halloran TV \& Woodruff TK 2012 A zinc-dependent mechanism regulates meiotic progression in mammalian oocytes. Biology of Reproduction 86 1-10. (doi:10.1095/biolreprod. 111.097253)

Cha KY, Choi DH, Koo JJ, Han SY, Ko JJ \& Yoon TK 1991 Pregnancy after in vitro fertilization of human follicular oocytes collected from nonstimulated cycles, their culture in vitro and their transfer in a donor oocyte program. Fertility and Sterility 55 109-113.

Child TJ, Abdul-Jalil AK, Gulekli B \& Tan SL 2001 In vitro maturation and fertilization of oocytes from unstimulated normal ovaries, polycystic ovaries, and women with polycystic ovary syndrome. Fertility and Sterility 76 936-942. (doi:10.1016/S0015-0282(01)02853-9)

Child TJ, Phillips SJ, Abdul-Jalil AK, Gulekli B \& Tan SL 2002 A comparison of in vitro maturation and in vitro fertilization for women with polycystic ovaries. Obstetrics and Gynecology 100 665-670. (doi:10.1016/S00297844(02)02193-2)

De La Fuente R \& Eppig J 2001 Transcriptional activity of the mouse oocyte genome: companion granulosa cells modulate transcription and chromatin remodeling. Developmental Biology 229 224-236. (doi:10.1006/ dbio.2000.9947)

Diaz FJ, O'Brien MJ, Wigglesworth K \& Eppig JJ 2006 The preantral granulosa cell to cumulus cell transition in the mouse ovary: development of competence to undergo expansion. Developmental Biology 299 91-104. (doi:10.1016/j.ydbio.2006.07.012)

Diaz F, Wigglesworth K \& Eppig J 2007 Oocytes determine cumulus cell lineage in mouse ovarian follicles. Journal of Cell Science $\mathbf{1 2 0}$ 1330-1340. (doi:10.1242/jcs.000968) 
Doherty AS, Mann MR, Tremblay KD, Bartolomei MS \& Schultz RM 2000 Differential effects of culture on imprinted $\mathrm{H} 19$ expression in the preimplantation mouse embryo. Biology of Reproduction 62 1526-1535. (doi:10.1095/biolreprod62.6.1526)

Eppig JJ, Pendola FL, Wigglesworth K \& Pendola JK 2005 Mouse oocytes regulate metabolic cooperativity between granulosa cells and oocytes: amino acid transport. Biology of Reproduction 73 351-357. (doi:10.1095/biolreprod.105.041798)

Gee KR, Zhou Z-L, Qian W-J \& Kennedy R 2002a Detection and imaging of zinc secretion from pancreatic $\beta$-cells using a new fluorescent zinc indicator. Journal of the American Chemical Society 124 776-778. (doi:10.1021/ja011774y)

Gee KR, Zhou ZL, Ton-That D, Sensi SL \& Weiss JH 2002b Measuring zinc in living cells. A new generation of sensitive and selective fluorescent probes. Cell Calcium 31 245-251. (doi:10.1016/S0143-4160 (02)00053-2)

Gilchrist RB, Ritter LJ, Myllymaa S, Kaivo-Oja N, Dragovic RA, Hickey TE, Ritvos O \& Mottershead DG 2006 Molecular basis of oocyte-paracrine signalling that promotes granulosa cell proliferation. Journal of Cell Science 119 3811-3821. (doi:10.1242/jcs.03105)

Gremeau A-S, Andreadis N, Fatum M, Craig J, Turner K, McVeigh E \& Child T 2012 In vitro maturation or in vitro fertilization for women with polycystic ovaries? A case-control study of 194 treatment cycles Fertility and Sterility 98 355-360. (doi:10.1016/j.fertnstert.2012.04.046)

Guzman L, Ortega-Hrepich C, Albuz FK, Verheyen G, Devroey P, Smitz I \& De Vos M 2012 Developmental capacity of in vitro-matured human oocytes retrieved from polycystic ovary syndrome ovaries containing no follicles larger than $6 \mathrm{~mm}$. Fertility and Sterility 98 503-507.e1-2. (doi:10.1016/j.fertnstert.2012.01.114)

Hussein TS, Froiland DA, Amato F, Thompson JG \& Gilchrist RB 2005 Oocytes prevent cumulus cell apoptosis by maintaining a morphogenic paracrine gradient of bone morphogenetic proteins. Journal of Cell Science 118 5257-5268. (doi:10.1242/jcs.02644)

Jou M-Y, Hall AG, Philipps AF, Kelleher SL \& Lonnerdal B 2009 Tissuespecific alterations in zinc transporter expression in intestine and liver reflect a threshold for homeostatic compensation during dietary zinc deficiency in weanling rats. Journal of Nutrition 139 835-841. (doi:10. 3945/jn.108.100974)

Kambe T, Yamaguchi-Iwai Y, Sasaki R \& Nagao M 2004 Overview of mammalian zinc transporters. Cellular and Molecular Life Sciences 61 49-68. (doi:10.1007/s00018-003-3148-y)

Kelleher SL, Velasquez V, Croxford TP, McCormick NH, Lopez V \& MacDavid J 2012 Mapping the zinc-transporting system in mammary cells: molecular analysis reveals a phenotype-dependent zinc-transporting network during lactation. Journal of Cellular Physiology 227 1761-1770. (doi:10.1002/jcp.22900)

Kim AM, Vogt S, O'Halloran TV \& Woodruff TK 2010 Zinc availability regulates exit from meiosis in maturing mammalian oocytes. Nature Chemical Biology 6 674-681. (doi:10.1038/nchembio.419)

Kim AM, Bernhardt ML, Kong BY, Ahn RW, Vogt S, Woodruff TK \& O'Halloran TV 2011 Zinc sparks are triggered by fertilization and facilitate cell cycle resumption in mammalian eggs. ACS Chemical Biology 6 716-723. (doi:10.1021/cb200084y)

Kong BY, Bernhardt ML, Kim AM, O'Halloran TV \& Woodruff TK 2012 Zinc maintains prophase I arrest in mouse oocytes through regulation of the MOS-MAPK pathway. Biology of Reproduction 87 1-12. (doi:10.1095/ biolreprod.112.099390)

Lichten LA \& Cousins RJ 2009 Mammalian zinc transporters: nutritional and physiologic regulation. Annual Review of Nutrition 29 153-176. (doi:10.1146/annurev-nutr-033009-083312)

Livak KJ \& Schmittgen TD 2001 Analysis of relative gene expression data using real-time quantitative PCR and the $2-$ [Delta] [Delta] $C T$ method. Methods 25 402-408. (doi:10.1006/meth.2001.1262)

Malcuit C, Trask MC, Santiago L, Beaudoin E, Tremblay KD \& Mager J 2009 Identification of novel oocyte and granulosa cell markers. Gene Expression Patterns 9 404-410. (doi:10.1016/j.gep.2009.06.004)

Mann MR, Lee SS, Doherty AS, Verona RI, Nolen LD, Schultz RM \& Bartolomei MS 2004 Selective loss of imprinting in the placenta following preimplantation development in culture. Development 131 3727-3735. (doi:10.1242/dev.01241)
Masui Y \& Markert CL 1971 Cytoplasmic control of nuclear behavior during meiotic maturation of frog oocytes. Journal of Experimental Zoology 177 129-146. (doi:10.1002/jez.1401770202)

Matzuk MM, Burns KH, Viveiros MM \& Eppig J 2002 Intercellular communication in the mammalian ovary: oocytes carry the conversation. Science 296 2178-2180. (doi:10.1126/science.1071965)

Merriman JA, Jennings PC, McLaughlin EA \& Jones KT 2012 Effect of aging on superovulation efficiency, aneuploidy rates, and sister chromatid cohesion in mice aged up to 15 months. Biology of Reproduction 49 41-46. (doi:10.1095/biolreprod.111.095711)

Nekola MV \& Nalbandov AV 1971 Morphological changes of rat follicular cells as influenced by oocytes. Biology of Reproduction 4 154-160.

Pincus G \& Enzmann EV 1935 The comparative behavior of mammalian eggs in vivo and in vitro. I. The activation of ovarian eggs. Journal of Experimental Medicine 62 655-675. (doi:10.1084/jem.62.5.665)

Rivera RM, Stein P, Weaver JR, Mager J, Schultz RM \& Bartolomei MS 2008 Manipulations of mouse embryos prior to implantation result in aberrant expression of imprinted genes on day 9.5 of development. Human Molecular Genetics 17 1-14. (doi:10.1093/hmg/ddm280)

Shoji S, Yoshida N, Amanai M, Ohgishi M, Fukui T, Fujimoto S, Nakano Y, Kajikawa E \& Perry ACF 2006 Mammalian Emi2 mediates cytostatic arrest and transduces the signal for meiotic exit via Cdc20. EMBO Journal 25 834-845. (doi:10.1038/sj.emboj.7600953)

Su YQ, Sugiura K, Wigglesworth K, O'Brien MJ, Affourtit JP, Pangas SA, Matzuk MM \& Eppig JJ 2008 Oocyte regulation of metabolic cooperativity between mouse cumulus cells and oocytes: BMP15 and GDF9 control cholesterol biosynthesis in cumulus cells. Development 135 111-121. (doi:10.1242/dev.009068)

Su YQ, Sugiura K, Li Q, Wigglesworth K, Matzuk MM \& Eppig JJ 2010 Mouse oocytes enable LH-induced maturation of the cumulus-oocyte complex via promoting EGF receptor-dependent signaling. Molecular Endocrinology 24 1230-1239. (doi:10.1210/me.2009-0497)

Sugiura K, Pendola FL \& Eppig JJ 2005 Oocyte control of metabolic cooperativity between oocytes and companion granulosa cells: energy metabolism. Developmental Biology 279 20-30. (doi:10.1016/j.ydbio. 2004.11.027)

Sugiura K, Su YQ, Diaz FJ, Pangas SA, Sharma S, Wigglesworth K, O'Brien MJ, Matzuk MM, Shimasaki S \& Eppig JJ 2007 Oocyte-derived BMP15 and FGFs cooperate to promote glycolysis in companion cumulus cells. Development 134 2593-2603. (doi:10.1242/dev.006882)

Suzuki T, Suzuki E, Yoshida N, Kubo A, Li H, Okuda E, Amanai M \& Perry ACF 2010a Mouse Emi2 as a distinctive regulatory hub in second meiotic metaphase. Development 137 3281-3291. (doi:10.1242/dev. 052480)

Suzuki T, Yoshida N, Suzuki E, Okuda E \& Perry ACF $2010 b$ Full-term mouse development by abolishing $\mathrm{Zn}^{2+}$-dependent metaphase II arrest without $\mathrm{Ca}^{2+}$ release. Development 137 2659-2669. (doi:10.1242/dev. 049791)

Tian X \& Diaz FJ 2012 Zinc depletion causes multiple defects in ovarian function during the periovulatory period in mice. Endocrinology 153 873-886. (doi:10.1210/en.2011-1599)

Tian X, Halfhill AN \& Diaz FJ 2010 Localization of phosphorylated SMAD proteins in granulosa cells, oocytes and oviduct of female mice. Gene Expression Patterns 10 105-112. (doi:10.1016/j.gep.2010.02.003)

Trounson A, Wood C \& Kausche A 1994 In vitro maturation and the fertilization and developmental competence of oocytes recovered from untreated polycystic ovarian patients. Fertility and Sterility 62 353-362.

Vanderhyden BC, Telfer EE \& Eppig JJ 1992 Mouse oocytes promote proliferation of granulosa cells from preantral and antral follicles in vitro. Biology of Reproduction 46 1196-1204. (doi:10.1095/biolreprod46.6. 1196)

Zhang M, Su Y-Q, Sugiura K, Xia G \& Eppig JJ 2010 Granulosa cell ligand NPPC and its receptor NPR2 maintain meiotic arrest in mouse oocytes. Science 330 366-369. (doi:10.1126/science.1193573)

Received 1 September 2012

First decision 29 October 2012

Revised manuscript received 9 January 2013

Accepted 4 February 2013 